\title{
Tsafon
}

Revue d'études juives du Nord

$78 \mid 2019$

L'antijudaïsme dans l'Antiquité

\section{Loridan-Ivens Marceline (avec Perrignon Judith), L'amour après}

Danielle Delmaire

\section{(2) OpenEdition}

1 Journals

Édition électronique

URL : https://journals.openedition.org/tsafon/2654

DOI : $10.4000 /$ tsafon. 2654

ISSN : 2609-6420

Éditeur

Association Jean-Marie Delmaire

Édition imprimée

Date de publication : 1 décembre 2019

Pagination : 184-185

ISSN : 1149-6630

\section{Référence électronique}

Danielle Delmaire, "Loridan-Ivens Marceline (avec Perrignon Judith), L'amour après », Tsafon [En ligne],

78 | 2019, mis en ligne le 01 décembre 2019, consulté le 25 juin 2021. URL : http://

journals.openedition.org/tsafon/2654 ; DOI : https://doi.org/10.4000/tsafon.2654

Ce document a été généré automatiquement le 25 juin 2021.

Tsafon. Revues d'études juives du Nord 


\title{
Loridan-Ivens Marceline (avec Perrignon Judith), L'amour après
}

\author{
Danielle Delmaire
}

\section{RÉFÉRENCE}

Paris, Grasset, Livre de poche, 158 p., 6,90€

1 Marceline Loridan-Ivens est bien connue pour ses réalisations cinématographiques notamment celles qu'elle effectua en partenariat avec son mari Joris Ivens. Son dernier film, achevé bien après la mort de son mari, est La petite prairie aux bouleaux (2003) qui évoque son parcours de déportée. Dans les dernières décennies, elle a aussi écrit ; nous pouvons retenir : Ma vie balagan (Laffont, 2008) et son dernier témoignage sur la disparition de son père à Auschwitz : Et tu n'es pas revenu (Grasset, 2015).

2 L'amour après est donc son dernier ouvrage-témoignage puisqu'elle est décédée le 18 septembre 2018 (lire notre rubrique «Informations » de notre $n^{\circ} 76$, décembre 2018, p. 183-184). Retrouvant ses lettres échangées avec ses amis, hommes, femmes, amants aussi, elle perce son passé de déportée et de militante pour la libération des femmes dans les années 1960-1970. Comment vivre l'amour après Auschwitz dont Marceline Loridan-Joris livre un aperçu de la réponse ? Cette instabilité amoureuse, voulue et complètement assumée, fut-elle une forme de résilience après Auschwitz ? "Fille de Birkenau ", proche de sa mort dont elle a pleinement conscience, " je vais mourir bientôt " (p. 13), elle fouille une valise contenant ces bouts de papier ou ces missives comme pour élaborer un bilan de sa vie qui fut "balagan " (mot utilisé par les Israéliens pour signifier que les choses sont sens dessus-dessous, que l'on est face à un « bazar », peu traduisible en français).

3 À la relecture de cette correspondance, elle se remémore ses aventures amoureuses, ses passades et d'autres plus durables. Elle retrouve aussi ses amies qui luttent pour leur liberté de femmes prises au piège d'une grossesse non voulue et de l'interdiction d'avorter. Une correspondante lui exprime son désarroi et Marceline Loridan-Ivens de 
remarquer : «Ses ratures montrent à quel point nous avions peur, à quel point c'était risqué d'avorter » (p. 67). Elle revit également l'ivresse de Saint-Germain-des-Prés des années cinquante, puis l'engagement auprès du FLN algérien dans les années soixante.

4 Bref ouvrage, brefs souvenirs que l'auteur livre alors qu'elle a conscience de sa mort bien proche, issue d'une vie de souffrance puis de «balagan ». 